\title{
Reprezentace obsahu: psychologická východiska a didaktické souvislosti ${ }^{1}$
}

\author{
Tomáš Janko \\ Masarykova univerzita, Pedagogická fakulta, Institut výzkumu školního vzdělávání
}

Redakci zasláno 29. 11. 2011 / Do tisku přijato 15. 3. 2012

\begin{abstract}
Abstrakt: Příspěvek má charakter teoretické přehledové studie týkající se problematiky reprezentace. Reprezentace představuje koncept, který se uplatňuje při analyzování a vysvětlování zákonitostí lidského poznávání, myšlení, komunikování a také učení. $V$ př́íspěvku jsou nejprve představována psychologická východiska konceptu reprezentace. Objasňováno je pojetía dělení pojmu reprezentace v kognitivní psychologii. Vymezovány jsou dvě základní formy vnějších reprezentací - jazyková a obrazová. V sociální psychologii koncept reprezentace slouží k vysvětlování toho, do jaké míry je individuální poznání determinováno socio-kulturními faktory. V příspěvku je naznačováno pojetí reprezentací vyplývající z Teorie sociálních reprezentací (Moscovici) a také z myšlenek L. S. Vygotského. Autor usiluje o rozpracování konceptu reprezentace pro potřeby didaktického diskursu. Přitom jsou vymezeny roviny, ve kterých učitel při operování s reprezentacemi během výuky uvažuje. Odkazováno je také k reprezentacím učiva, které hrají důležitou roli při zpřístupňování obsahu vzdělávání žákům.
\end{abstract}

Klíčová slova: reprezentace, didaktická transformace, obsah vzdělávání

\section{1 Úvod}

Obsah vzdělávání je privilegovaným hlediskem edukace. Privilegovanost vyplývá ze skutečnosti, že výuka bez obsahu by nebyla možná anebo by byla nesmyslná (srov. Staub, Westová, \& Bickelová, 2003, s. 9). Výjimečné postavení obsahu ve vzdělávání vyzývá k tomu, aby se k jeho rekonstruování ve výuce přistupovalo s náležitou odpovědností (srov. Štech, 2009, s. 108). Zdrojem obsahu školního vzdělávání jsou zpravidla vědní či umělecké a jiné obory. Zároveň s tím však žáci do výuky vstupují s vlastními představami a prekoncepty, tj. s určitým předporozuměním pro to, co se bude vyučovat. Toto předporozumění staví na předcházejících zkušenostech, ale zpravidla

1 Studie vznikla za podpory projektu MUNI/A/0883/2011 Školní vzdělávání: podmínky, aktéři, kurikulum, procesy, výsledky (SKOLA 2012). Zpracování bylo podpořeno Stipendijním programem PdF MU.

DOI: $10.5817 /$ PedOr2012-1-23 
nepostačuje pro bezprostřední porozumění oborovému obsahu. Proto je nutné oborový obsah nejprve odpovídajícím způsobem transformovat pro účely vzdělávání. Transformování obsahu probíhá na třech úrovních: (1) ontodidaktické, jejímž smyslem je převedení oborových obsahů na obsahy kurikulární; (2) psychodidaktické, která umožňuje transformaci kurikulárních obsahů do roviny výuky a (3) kognitivní, během níž dochází ke kognitivnímu zpracovávání obsahu žáky (srov. Janík, Maňák, \& Knecht, 2009, s. 37-43). Z hlediska námi analyzované problematiky je zásadní zejména úroveň psychodidaktické transformace. Na této úrovni by mělo docházet k psychologizování obsahu. To znamená, že při zpř́ístupňování a přibližování vzdělávacího obsahu žákům by měla být zajištěna návaznost na kognitivní možnosti a subjektivní zkušenosti žáků.

Jedním z konceptů, které se uplatňují při vysvětlování toho, jakým způsobem by měl být obsah vzdělávání ve výuce transformován, aby byla zajištěna návaznost na kognitivní možnosti žáků, je koncept reprezentace. Tento koncept je pro didaktiku zásadní. Postihuje totiž předmět didaktiky v samém jeho jádru; na pomezí mezi oborovými koncepty a žákovskými prekoncepty. I přes její explanační potenciál ale problematika reprezentace není v didaktice dosud dostatečně etablovaná. Vedle didaktiky je koncept reprezentace rozpracováván také $\mathrm{v}$ dalších oborech. Zejména v kognitivní a sociální psychologii. Domníváme se, že integrace poznatků z uvedených oborů může přispět $\mathrm{k}$ hlubšímu porozumění konceptu reprezentace a také prohloubenému poznání jeho potenciálu pro potřeby didaktiky.

V této studii nejprve představíme kognitivně a sociálně psychologická východiska konceptu reprezentace. Dále se pokusíme rozpracovat tento koncept pro potřeby didaktického diskursu. Věnovat se budeme rovinám, ve kterých učitel při operování s reprezentacemi během výuky uvažuje, a také reprezentacím učiva, které hrají důležitou roli při zpřístupňování obsahu vzdělávání žákům.

\section{Psychologická východiska konceptu reprezentace}

V tomto př́spěvku usilujeme o zhodnocení konceptu reprezentace z hlediska didaktiky. Problematika reprezentace je však uchopována i v dalších oborech. Poznatky představující důležitý kontext pro uchopování reprezentace $\mathrm{v}$ didaktice byly systematicky zkoumány zejména $\mathrm{v}$ kognitivní a sociální psychologii. Dále se proto pokusíme o jejich stručné přiblížení. 


\subsection{Koncept reprezentace z kognitivně psychologického pohledu}

Otázka, jakým způsobem jsou v lidské mysli reprezentovány poznatky o reálném světě, přitahuje odborníky již desítky let (Eysenck \& Keane, 2008, s. 297). Intenzivní výzkum problematiky reprezentace probíhal v kognitivní psychologii zejména na přelomu 60 . a 70. let a pokračoval také v 80 . letech 20. století (Sedláková, 2004, s. 59). Jak uvádí Sedláková (1992, s. 290-291) předpokladem pro zavedení a etablování konceptu reprezentace v kognitivní psychologii byl rozvoj počítačového paradigmatu. Počítačové paradigma souvisí s analyzováním analogií mezi kognitivními procesy u člověka a algoritmy zpracovávání informací v počítači. Problematika reprezentace nabyla v kognitivní psychologii na významu také v souvislosti s výzkumem umělé inteligence (srov. Ruisel \& Ruiselová, 1990, s. 55-63).

Reprezentace $\mathrm{V}$ kognitivní psychologii představuje téma, $\mathrm{z}$ jehož výzkumného uchopování vyplývá řada zásadních poznatků, umožňujících vysvětlování procesů zapojených do lidského poznávání, myšlení a také učení. Problematikou reprezentace se v teoretické i empirické rovině, zabývá řada odborníků. Z množství existujících prací vybíráme například studie Jorny (1990), Najdera, (1989), Engelkampa a Pechmanna (1988). V českém prostředí byl koncept reprezentace v kognitivní psychologii rozpracováván zejména Sedlákovou (napr. 2004, 1992 ad.). Podle Sedlákové (2004, s. 44) lze pojem reprezentace odvozovat z předpony re (znovu) a z latinského slova praesento (zpřítomňuji, představuji). Pojem tak odkazuje $\mathrm{k}$ opětovnému zpř́tomňování, respektive představování ${ }^{2}$. Reprezentaci lze z kognitivněpsychologického hlediska chápat také jako psychické zobrazení s převahou myšlenkových procesů, které představuje jednak samotný proces kognice, jednak jeho výsledek (srov. Stř́žženec, 1982, s. 534-543). Výsledkem přitom může být cokoliv od psychického obrazu až po složité myšlenkové konstrukce.

Reprezentace mohou sloužit také jako nástroj regulující psychické procesy a jednání jedince. Děje se tak z proto, že aktivním reprezentováním aspektů vnějšího světa se v mysli jedince utváří určitá struktura poznatků, která následně ovlivňuje začleňování nových informací - konkrétně jejich zpracovávání, organizování a zapamatování (srov. Norman, 1979; cit. podle Ruisel \& Ruiselová, 1990, s. 72-73). Tento poznatek kognitivní psychologie je velmi důležitý pro obsahové pojetí didaktiky, jak ukážeme dále.

Může se jednat o představování na úrovni smyslových představ, ale také o představování na úrovni pojmů. 
V současnosti je koncept reprezentace v kognitivní psychologii uchopován především v souvislosti se snahou o vysvětlování psychických procesů podílejících se na utváření vnitřního subjektivního světa jedince. Klíčová otázka zní: Jakým způsobem jsou v lidské mysli reprezentovány poznatky, vznikající na základě kognitivního zpracovávání „vnějších“ podnětů různé modality (srov. Eysenck \& Keane, 2008, s. 297).

Reprezentování „vnějšího“ obsahu v lidské mysli je závislé na propojení dřivější zkušenosti $s$ aktuálně vnímaným objektem. Obecně to znamená, že každá reprezentace spočívá $\mathrm{v}$ referenci, tj. ve vytvoření vztahu mezi aktuálně pozorovaným objektem a tím, k čemu má tento objekt odkazovat (at' již $\mathrm{k}$ jednotlivině nebo ke tř́dě objektů či k určité vlastnosti). Jde tedy o vytvoření referenčního vztahu mezi reprezentujícím (tím, co odkazuje) a reprezentovaným (tím, k čemu je odkazováno). Tuto skutečnost bychom mohli objasnit prostřednictvím jednoduchého př́kladu. Červená barva objektu, který aktuálně vnímáme, odkazuje k obsahové reprezentaci všech červených objektů, které jsme již někdy před tím vnímali. Pokud tedy jsme schopni opakovaně rozpoznávat červenou barvu, je to na základě její obsahové reprezentace, která umožňuje sdružovat všechny červené objekty do jedné třídy.

$\mathrm{V}$ kognitivní psychologii se $\mathrm{v}$ souvislosti $\mathrm{s}$ tím pozornost zaměřuje na analyzování forem, $\mathrm{v}$ nichž jsou $\mathrm{v}$ lidské mysli zpracovávány a ukládány poznatky. Situace je však do určité míry komplikována skutečností, že v kognitivní psychologii existuje několik pojetí reprezentace. Jednotlivá pojetí se odlišují v tom, jaké kognitivní procesy a mechanismy předpokládají při organizaci a reprezentaci podnětů různého druhu (modality) ${ }^{3}$. I když jsou mezi jednotlivými pojetími reprezentace určité rozdíly, existuje hledisko, které je společné všem teoriím reprezentace. Tímto hlediskem je chápání reprezentace jako relace mezi reprezentujícím a reprezentovaným. Předpoklad, že objekt, který vnímáme tady a ted', musí být $\mathrm{v}$ nějaké souvislosti s objektem, který jsme již někdy vnímali (např. v minulosti), není zpochybňován žádným z existujících pojetí.

Rozdíly mezi jednotlivými pojetími se následně odrážejí ve vymezování odlišných forem reprezentace. Podrobnějším porovnáváním forem reprezentace se však dále nebudeme zabývat, není to ani smyslem tohoto příspěvku. Shrnující přehled forem reprezentace, rozlišovaných v kognitivní psychologii nabízí například Sedláková (2004, s. 68-69; viz také 1992, s. 293-306). Podle Sedlákové je v kognitivní psychologii v současnosti rozlišováno již 11 forem mentální reprezentace. 
Zároveň však vyvstává otázka, na základě jakých principů by bylo možné souvislosti mezi reprezentujícím a reprezentovaným vymezit. Současná pojetí reprezentace vycházejí z jednoho ze dvou „základních“ pojetí. „Tradiční pojetí vymezené J. Piagetem definuje reprezentaci (reprezentující relaci) na základě podobnosti. Definování reprezentace na základě podobnosti se však postupně ukázalo jako nedostačující. Později proto bylo přehodnoceno a nově definováno N. Goodmanem (např. Goodman, 2007). Goodmanovo pojetí chápe reprezentaci jako vztah, který může být charakterizován směrem odkazování. To znamená,že reprezentace je vymezována na základě vlastností reprezentující relace ${ }^{4}$. Reprezentace by měla být asymetrická a jedinečná. Měla by rovněž umožňovat vytváření misreprezentací ( $\mathrm{tj}$. umožňovat chyby nebo falzifikace) a také dovolovat reprezentování neexistujících (fikčních) objektů (srov. Sedláková, 2004, s. 50-51). Zásadní přitom je, aby byla splněna podmínka intencionality a obsahové identity, tzn., že něco je reprezentováno jako něco a ne jako něco jiného.

Pro účely tohoto příspěvku si vystačíme s dělením reprezentací na vnitřní (mentální) a vnější (někdy označované také jako externí). Jedná se o informaci, kterou se zde budeme ještě zabývat, i když v jiných souvislostech (viz kap. 2). V kognitivní psychologii se výzkumná pozornost zaměřuje na analyzování mentálních reprezentací. Cílem je objasnit, jakou roli hrají reprezentace při mentálních aktivitách, jako je např. vnímání, mluvení, myšlení, řešení problémů anebo učení. V souvislosti s tím jsou v kognitivní psychologii vymezovány jednoduché a smíšené (někdy označované jako vícečetné - multiple) formy mentálních reprezentací. Některými autory jsou vymezovány také tzv. vyšší formy mentální reprezentace. Př́́kladem může být např́íklad mentální model. Ten lze chápat jako propracovanější formu mentální reprezentace, která obsahuje subjektivně důležité informace o určitém jevu a je aktivována obvykle při uvažování a řešení problémů (Sedláková, 2004, s. 123-150; viz také např. Johnson-Laird, 1983).

Z kognitivně psychologického pohledu je podstatné rozlišování symbolické a subsymbolické formy mentální reprezentace. Jedná se o formy, které se

\footnotetext{
Goodman rozlišuje tř̌i základní typy reprezentace. První z nich, denotace, odkazuje ve směru od objektu označujícího k objektům označovaným. Např. slovo „červená“ denotuje červenou barvu. Druhý z nich, tzv. exemplifikace, odkazuje v opačném směru, protože předvádí vybrané vlastnosti reprezentované tř́́dy objektů. Např. červený míč exemplifikuje červenou barvu podobně jako červená třešeň anebo jiné červené věci. A třetí typ, tzv. exprese, má opět stejný směr jako exemplifikace, ale na rozdíl od ní není doslovným, ale metaforickým převedením. Např. šedý obraz doslovně exemplifikuje šedou barvu, ale metaforicky exemplifikuje smutek (srov. Goodman, 2007).
} 
odlišují v tom, jakým způsobem (resp. jakými výrazovými prostředky) jsou $\mathrm{v}$ nich reprezentovány obsahy mysli jednice. Zatímco symbolickou reprezentaci lze chápat jako „tradiční" pojetí mentální reprezentace, subsymbolická reprezentace, byla do kognitivní psychologie uved ena později, $\mathrm{v}$ souvislosti $\mathrm{s}$ paradigmatem konekcionismu ${ }^{5}$. Symbolická reprezentace je dále dělena na propoziční a analogovou (imaginativní) reprezentaci (srov. Eysenck \& Keane, 2008, s. 335-341). V propoziční reprezentaci jsou informace organizovány do tzv. propozic. Ty si lze zjednodušeně představit jako sít' sestávající z uzlů (představujících určité pojmy; např. kniha, stůl), které jsou navzájem propojeny spojnicemi (sloužícími k označování vztahů; např. být na něčem). Naproti tomu analogická reprezentace je s objektem, který reprezentuje, spojena na základě analogie. Je výsledkem představivosti a umožňuje re-prezentování objektů na základě smyslových představ, např. zrakových, sluchových, čichových ad.

Rozlišování propozičních a analogických reprezentací, jež se uplatňují při uchovávání obsahů lidské mysli, má nicméně základ v rozlišování odpovídajících reprezentací vnějších. $\mathrm{V}$ souvislosti $\mathrm{s}$ analyzováním kognitivních (mentálních) procesů se tak předmětem pozornosti stávají i reprezentace vnější. Jak uvádějí Eysenck a Keane (2008, s. 298) s vnějšími reprezentacemi se lze setkat nejčastěji ve formě jazykových reprezentací nebo obrazových reprezentací. Podobně jako u propozičních a analogických reprezentací i jazykové a obrazové reprezentace se odlišují v tom, jaké výrazové prostředky využívají k reprezentování obsahů (srov. tabulka 1).

\section{Tabulka 1}

Shrnutí rozdílů mezi jazykovou a obrazovou reprezentací

\begin{tabular}{ll}
\hline jazyková reprezentace & obrazová reprezentace \\
\hline diskrétní & nediskrétní \\
explicitní & implicitní \\
silná kombinační pravidla & volnější kombinační pravidla \\
smyslově amodální & modálně specifická \\
(není vázána na konkrétní smyslový kanál) & (vázána na konkrétní smyslový kanál) \\
\hline
\end{tabular}

Pozn.: Upraveno podle Eysenck a Keane (2008, s. 301).

5 Konekcionismus představuje myšlenkový proudv rámci kognitivní psychologie. Reprezentace a kognitivní procesy zapojené do zpracovávání informací modeluje jako „mentální sítě“. Každá sít' je tvořena uzly (významy), které jsou navzájem propojeny relacemi (vztahy; srov. např. Sedláková, 2004, s. 35-38). 
Je patrné, že pro vnější jazykovou reprezentaci jsou charakteristické diskrétní nespojité symboly, explicitně vyjádřené vztahy a specifická gramatická pravidla pro kombinování znaků (písmen). Naproti tomu u obrazové reprezentace se kombinování symbolů, reprezentujících různé objekty a vztahy mezi nimi, řídí jinými pravidly sdružování částí do celků. Rozdíly mezi zmiňovanými formami vnějších reprezentací se potom mohou odrážet ve způsobu, jakým s nimi žáci (např během školní výuky) kognitivně interagují. A v konečném důsledku mohou vést $\mathrm{k}$ vytváření kvalitativně odlišných mentálních reprezentací.

V souhrnném pohledu můžeme konstatovat, že i když se analyzování problematiky reprezentace $\mathrm{v}$ rámci kognitivní psychologie může jevit jako poměrně abstraktní, jedná se o zásadní téma. $\mathrm{V}$ kapitole jsme usilovali o nastínění, jakým způsobem je konceptreprezentace uchopován z kognitivněpsychologického hlediska. Zaměřili jsme se na popsání forem reprezentace, v nichž mohou být v lidské mysli reprezentovány poznatky různé modality. Problematika reprezentace je však v rámci kognitivní psychologie řešena mnohem komplexněji, než jak jsme ji byli schopni popsat. Jako doplnění proto dále nabízíme schéma shrnující základní dělení pojmu reprezentace v kognitivní psychologii (viz obrázek 1).

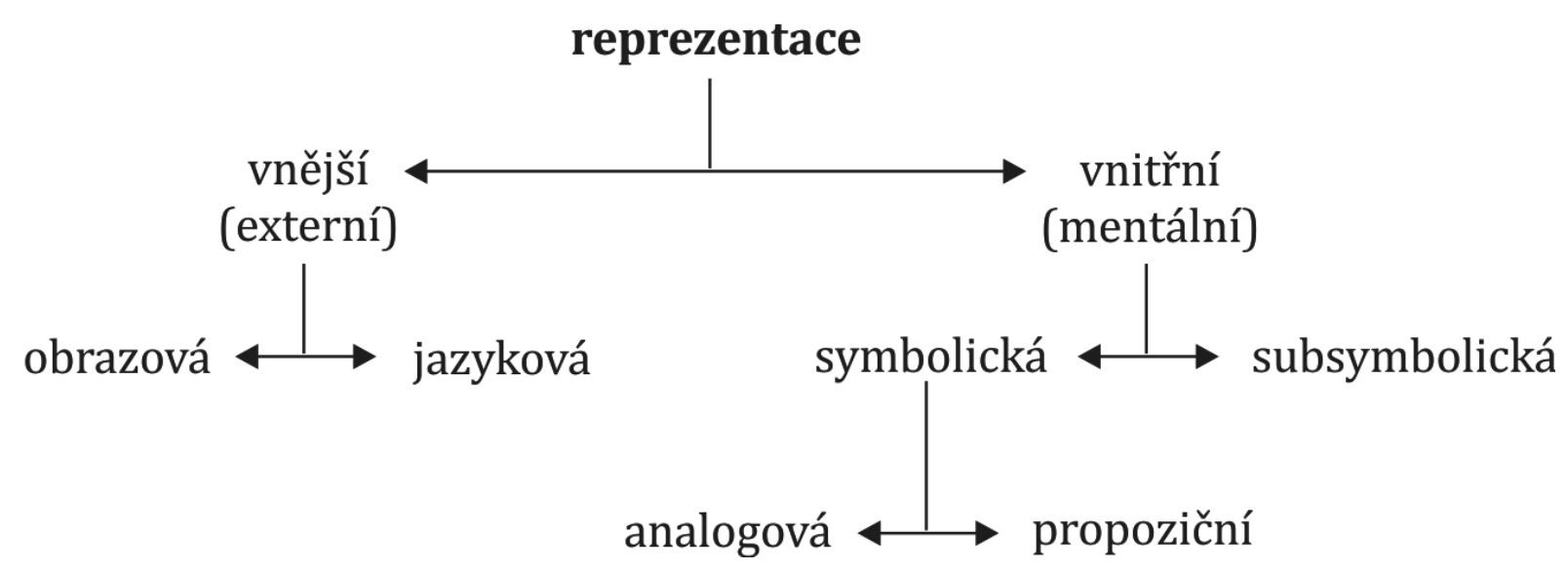

Obrázek 1: Základní dělení pojmu reprezentace v kognitivní psychologii. Upraveno podle Sedláková (2004, s. 54). 


\subsection{Koncept reprezentace ze sociálně-psychologického hlediska}

Naznačili jsme, že v kognitivní psychologii je koncept reprezentace uchopován v souvislosti se zkoumáním vnitřního světa jedince a odhalováním zákonitostí individuálního poznávání. Při současné úrovni vědeckého poznání však není reálné, aby jedinec utvářel své poznání pouze na základě vlastního subjektivního „znovuobjevování“. Je tak do značné míry odkázán na poznatky, které jsou mu nějakým způsobem zprostředkovávány. Člověk je také tvor společenský, jeho vnímání, poznávání a učení neprobíhá ve vakuu, ale vždy v určitém sociálním prostředí. Je tedy patrné, že reprezentace představuje důležitý koncept také ze sociálně-psychologického hlediska. V sociální psychologii se koncept reprezentace uplatňuje zejména při hledání odpovědi na otázku, do jaké míry je poznávání a učení výsledkem individuálního kognitivního úsilí jedince, a do jaké míry je ovlivněno společenským diskursem.

K rozpracování konceptu reprezentace $\mathrm{v}$ sociální psychologii přispěli na přelomu 19. a 20. století francouzští sociologové E. Durkheim a S. Moscovici. Durkheim dal konceptu reprezentace explicitně sociální význam a umístil ho do středu sociologické teorie poznání. Durkheimův přínos spočívá také v rozlišení individuálních a kolektivních reprezentací (srov. Marková, 2007, s. 167). Individuální reprezentace ${ }^{6}$ podle Durkheima nepřispívají k poznání reality, protože jsou proměnlivé a subjektivní. Naproti tomu kolektivní reprezentace zahrnují všechny sociálně produkované fenomény, které jsou sdíleny a kolektivně ověřovány $\mathrm{v}$ určité společnosti. Představují tak klíč pro porozumění vnějšímu světu a stojí nad reprezentacemi individuálními. Mladší pojetí problematiky reprezentace v sociální psychologii představuje francouzský psycholog Moscovici (např. 1961, 1985). Moscovici chápe reprezentace jako soubor názorů a přesvědčení, které se utváří a cirkulují ve společnosti. Jako takové umožňují efektivní komunikaci, usnadňují sdílení společných cílů a vykonávání společných činností. Moscovici je také autorem ucelené Teorie sociálních reprezentací, která vychází z předpokladu, že reprezentace určitého fenoménu není produktem individuálních myslí, ale myslí interagujících a komunikujících v určitém sociálním prostředí. Reprezentace jsou potom chápány jako produkty sociálního života a jsou analyzovány na úrovni jednotlivců, skupin, či společenského diskursu, a to jak současného, tak i historického (srov. Plichtová, 2002, s. 31-32).

6 Ty lze v rámci tohoto př́spěvku chápat jako ekvivalent vnitřních (mentálních) reprezentací. 
Důležitý rámec pro vysvětlování problematiky reprezentace ze sociálně psychologického hlediska představují myšlenky L. S. Vygotského. Vygotskij (2004) se zabývá vysvětlováním sociokulturní podmíněnosti mentálních procesů probíhajících v lidské mysli. V souvislosti s tím kritizuje vyloučení sociálních a kulturních faktorů ze zkoumání mentálních procesů. Odmítá rovněžredukovánílidské mysli na systém abstraktních mechanismůa struktur. Naopak, lidská mysl je podle Vygotského významně determinována sociálně kulturními faktory. Myšlenky Vygotského směrem k učení a problematice reprezentace rozpracovává např. Petrová (2008).

Podle autorky lze školní vzdělávání, v kontextu Vygotského teorie, chápat jako socializaci psychických funkcí jedince s důrazem na transfer společenského poznání předcházejících generací na generaci následující. Smyslem vzdělávání potom není naplnění individuálních vzdělávacích potřeb žáka, ale spíše nalezení a uplatňování metod, které umožňují co nejefektivnější přenos kulturně akceptovaných fenoménů, čímž mohou přispívat k rozvoji psychických funkcí každého žáka - člena společnosti (Petrová, 2008, s. 8). Optikou uvedených skutečností Petrová analyzuje také reprezentace. Ty chápe jako „kulturní nástroje“ sloužící ke zprostředkovávání společenského poznání a vývoje (Petrová, 2008, s. 15). Klíčová otázka zní: Jak by měly být reprezentace konstruovány, aby podporovaly transformaci interpsychického obsahu do intrapsychické podoby? Podle Petrové (viz výše) je při hledání odpovědi nutné zohledňovat zejména následující faktory: (1) povahu kulturního nástroje a také (2) způsob jeho používání v interpersonálních vztazích (Petrová, 2008, s. 32).

V souhrnném pohledu se tedy ukazuje, že problematika reprezentace v sociální psychologii slouží k vysvětlování interakce mezi individuálními reprezentacemi $\mathrm{v}$ kontextu sociálního prostředí, které podmiňuje jejich význam a smysl. Pozornost se přitom zaměřuje na zodpovězení otázky, zda (resp. do jaké míry) jsou reprezentace určitého fenoménu výsledkem individuálního kognitivního úsilí a do jaké míry jsou ovlivněny společenským konsensem o daném fenoménu. V souvislosti s tím jsou předmětem zkoumání reprezentace jedinců v různých sociálních pozicích anebo sociálních rolích.

\section{Didaktické souvislosti konceptu reprezentace}

Doposud jsme se v příspěvku zabývali převážně psychologickými východisky pojmu reprezentace. Usilovali jsme o popsání toho, jakým způsobem je 
reprezentace uchopována $\mathrm{z}$ hlediska kognitivně-psychologického a také sociálně-psychologického. $\mathrm{V}$ souvislosti s tím jsme uvedli poznatky, které dle našeho názoru představují relevantní kontext pro uchopování konceptu $\mathrm{z}$ pohledu didaktiky. $\mathrm{V}$ návaznosti na to dále usilujeme o rozpracování didaktických souvislostí konceptu reprezentace.

Koncept reprezentace má pro didaktiku zásadní význam. Postihuje totiž předmět didaktiky v samém jeho jádru, tj. na pomezí oborových konceptů a žákovských prekonceptů. Jedná se o to, že jak v oborech, tak v žákovské zkušenosti je východiskem jakéhokoliv uvažování schopnost klasifikovat objekty do tříd, tzn. přisuzovat jim význam. Jinými slovy, pracovat s referencemi mezi aktuálně př́tomným objektem a tím, k čemu tento objekt odkazuje. Žáci se již na samém počátku školního vzdělávání učí písmena abecedy, číslice, geometrické objekty: jejich osvojení závisí na schopnosti třídění a obsahové reprezentace. Přičemž nabytí schopnosti obsahové reprezentace závisí na dostatečně bohaté činnosti s příslušnými objekty: aby dítě pochopilo, co jsou čísla, musí umět počítat, aby pochopilo písmena, umět číst a psát. Podobně to platí třeba pro chemické vzorce nebo biologické, fyzikální a jiné poznatky.

Vzhledem k tomu se koncept reprezentace významně uplatňuje při vysvětlování didaktické transformace obsahu vzdělávání. Důležitou roli hraje také při objasňování problematiky konceptuálního učení a konceptuální změny. Reprezentace je z pohledu didaktiky zásadní také z jiného důvodu. Učitelé $s$ úmyslem přibližovat obsah vzdělávání žákům, vytvářejí během školní výuky odkazy $\mathrm{k}$ fenoménům bezprostředně. Vytváření referencí mezi reprezentujícími objekty a reprezentovanými fenomény tak lze považovat za přirozenou součást práce učitele. Shulman (např. 1986, 1987) v této souvislosti mluví o didaktických znalostech obsahu jako o dispozici učitele uvádět př́klady nebo alternativní reprezentace.

Usilujeme-li však o rozpracování konceptu reprezentace pro účely didaktiky, potřebujeme zřetelněji naznačit vztah mezi psychologickým pojmem reprezentace a jemu odpovídajícími konstrukty didaktického diskursu. Poznatky týkající se konceptu reprezentace pocházející z různých oborů se mohou dobře doplňovat. Jak jsme již naznačili, reprezentace odráží intencionální vztah mezi reprezentujícím a reprezentovaným, který může být uskutečňován například prostřednictvím denotování (odkazování) anebo exemplifikování (uváděním příkladů či vzorků) k určitému fenoménu (srov. např. Slavík, 2011, s. 213-214). Tento vztah je relevantní i z hlediska 
didaktického a může představovat jak východisko, tak předmět učení. Např. učitel chemie reprezentuje-denotuje vodu vzorcem $\mathrm{H}_{2} \mathrm{O}$ a exemplifikuje ji $\mathrm{v}$ podobě skutečné tekoucí vody, ledu, sněhu, mlhy apod. Didaktický pohled na reprezentaci se tak opírá o poznatky získané psychologií (která se problematikou zabývá spíše v obecné rovině) a zdůrazňuje přitom obsahové a významové aspekty reprezentace.

Reprezentace má smysl, pouze pokud je intencionální, tj. pokud je zaměřená na něco (srov. Perner, 1993; Dennet, 2004 ad.). Z didaktického hlediska jsou nejobecnějšími pojmy pro tuto zaměřenost „obsah“ vzdělávání a jeho „význam“. Didaktické rekonstruování anebo transformování obsahu je enkulturační proces, který obohacuje, rozvíjí a upřesňuje subjektivní obsahové reprezentace žáků. Obsah vzdělávání a komunikování jeho významů lze tedy chápat jako jakýsi „spojující most“ mezi psychologickým pohledem na teorii reprezentace a konceptem didaktické transformace obsahu.

Smyslem výuky je žáky něčemu naučit. Během výuky dochází $k$ tomu, že žáci kognitivně interagují s obsahem vzdělání a usilují o jeho subjektivní uchopení. Díky své snaze o ovládnutí obsahu žáci vstupují do intersubjektivního prostoru, $v$ němž dochází $\mathrm{k}$ utváření a komunikování významů. Ve výuce žáci prověřují své schopnosti pro vyjádření určitého obsahu, pro jeho sdělování druhým a pro zdůvodňování svých reprezentací. Smyslem výuky tak není jen naučit žáky jak obsahu porozumět, ale také jak se o obsahu dorozumět s druhými (srov. Janík \& Slavík, 2009, s. 117).

Abychom mohli souvislost mezi konceptem reprezentace a didaktickou transformací obsahu objasnit podrobněji, potřebujeme dále vymezit analytické jednotky obsahové transformace. Vymezení těchto analytických jednotek nám umožní reflektovat způsoby uchopování obsahu vzdělávání a uvolní nám cestu $\mathrm{k}$ propojení konceptu reprezentace a konceptu didaktické transformace obsahu. Východisko pro naši snahu představuje Model didaktické rekonstrukce (Jelemenská, Sander, \& Kattmann, 2003). Model představuje teoretický rámec pro zkoumání zákonitostí vyučování a učení. Základními komponentami „účinkujícími“ při utváření vzdělávacího obsahu jsou: objasňování oborových představ, výzkum žákovských představ a didaktická strukturace učebního prostředí (srov. Jelemenská, 2009, s. 147). Oborové představy a žákovské představy jsou $\mathrm{v}$ modelu chápány jako rovnocenné zdroje pro rekonstruování obsahu vyučování a učení. 
Z výše uvedeného vyplývá, že učitel by měl během výuky uvažovat a balancovat mezi třemi rovinami reprezentace, které propojují subjekt s intersubjektivním (socio-kulturním) kontextem.

- Jsou to jednak představy žáků (P), které jsou výsledkem subjektivního uchopování obsahu. Představy žákư7 odpovídají mentálním strukturám, které „má žák v hlavě“. Z vnějšku jsou však dostupné jen prostřednictvím nějakého smyslově zachytitelného projevu.

- Během výuky se představy žáků projevují prostřednictvím odpovídajících výrazů (Q), respektive výrazových konstrukcí (tj. konkrétního způsobu utváření výrazu). Cílem výuky je způsobovat změny $\mathrm{v}$ představách žáků, které se mohou projevovat $\mathrm{v}$ jejich výrazech.

- Aby však tyto změny byly pozitivní, musí mít nějaký obecně srozumitelný a obecně přijatelný rámec - kontext. Tímto kontextem jsou kulturně etablované výrazové konstrukce, tj. např. správně gramaticky a sémanticky vytvořené věty, odborně korektní definice, kulturně vžité způsoby zobrazování apod. Tyto kulturně etablované výrazy označíme (R). Jejich analogií v Modelu didaktické rekonstrukce jsou „představy vědců“, tj. obecně vzato odborné, kulturou vstř́ícně přijímané ideje. Vưči nim žáci mohou a mají vymezovat své operování $s$ představami.

Například původní žákova představa, že Země je dokonalá koule jako školní glóbus, může být upřesněna s ohledem na současné poznatky skutečného tvaru Země (podrobněji viz Janík \& Slavík, 2009, s. 120-123). Vztahy mezi uvedenými komponentami by pro názornost bylo možné graficky znázornit následujícím způsobem:

$$
P \longleftrightarrow Q \longleftrightarrow R
$$

Jak vyplývá $\mathrm{z}$ odlišení $(\mathrm{P})$ od $(\mathrm{R})$ ve výše uvedeném schématu, v souvislosti s vysvětlováním problematiky reprezentace se do hry dostávají dva „protipóly“ - žákovské představy (P) vyjádřené výrazem (Q) a oborové představy vyjádřené výrazem (R). Analyzování žákovských představ $\mathrm{v}$ odborném oborovém kontextu představuje výzkumné téma, kterým se zabývá řada domácích i zahraničních autorů. V kontextu didaktické

7 V jiném výkladovém rámci označované jako prekoncepty. 
transformace se žákovskými představami (resp. dětskými pojetími) zabývají např. Doulík a Škoda (2010). Autoři uvádějí, že žákovské představy nelze při porovnávání s vědeckými koncepty chápat apriori jako mylné. Naopak, jejich variabilitu je nutné hodnotit z hlediska odpovídajícího sociokulturního kontextu. Představy žáků tak během výuky možné jednoduše nahrazovat obsahy vyučovacích předmětů. Naopak obsahy je nutné v myslích žáků rekonstruovat (srov. Doulík \& Škoda, 2010, s. 25-26).

Několikrát jsme v příspěvku poukázali na pojem výrazová konstrukce. Uvedli jsme, že se jedná o způsoby konkrétního vyjádření obsahu. Jinými slovy, výrazová konstrukce je způsob vyjádření představy, resp. pojmu, je to vnější obsahová reprezentace. Nejnáročnějšími podobami výrazových konstrukcí je např. vědecký text nebo umělecké dílo, vrcholný sportovní výkon apod. Slovem „konstrukce“ zdůrazňujeme tvůrčí charakter, nutnost ji určitým postupem vytvořit, postupně ji vybudovat.

Učitel se při výuce setkává s výrazovými konstrukcemi svých žáků a konfrontuje je s jejich kulturně ideálními alternativami, které pocházejí z jednotlivých oborů. Např. zápis slova Přibyslav je jednoduchá výrazová konstrukce stejně jako zápis součtu $2+5$, zacvičení kotoulu vpřed nebo nakreslený pejsek. Každou z těchto konstrukcí lze realizovat lépe, či hůře, bez chyb, nebo s chybou, tvořivěji, nebo méně tvořivě.

Žáci se $\mathrm{v}$ průběhu školní výuky seznamují s různě složitými fenomény pocházejícími z různých oborů lidského poznání (podrobněji viz např. Slavík \& Janík, 2007, s. 265-267). Ne vždy je možné se s těmito fenomény konfrontovat př́mo. Během výuky jsou fenomény transformovány do podoby, která více respektuje kognitivní možnosti a výrazové prostředky žáka ${ }^{8}$.

Učitel, aby učinil obsah vzdělávání přístupnějším a srozumitelnějším pro žáky, může ve výuce využívat rozmanitých výrazových konstrukcí. Ty si lze představit jako různé didakticky uzpůsobené formy prezentování, vysvětlování a objasňování obsahu. Může jít rovněž o rozmanité analogie, metafory, modely demonstrace apod. Pro označování těchto různorodých způsobů přibližování obsahu (transformovaných oborových představ) žákům je používán pojem reprezentace učiva (srov. Janík, Maňák, \& Knecht, 2009, s. 111).

8 Obsahy vzdělávání přitom mohou být strukturovány různými způsoby - např. (1) lineárně jako text, ale také (2) nelineárně, např. jako schémata, grafy, nonverbální prvky apod. (srov. Mareš, 2001, s. 452). 
Uvedené skutečnosti bychom mohli jednoduše vysvětlit na př́ikladu učiva matematiky, konkrétně na příkladu učiva celých čísel. Vezměme například číslo devět. Počet devět je možné reprezentovat prostřednictvím různých výrazových konstrukcí: např. $3 * 3,3^{2}, 5+4$ ad. Rozdíl mezi těmito výrazovými konstrukcemi je z didaktického pohledu závažný. Výběr a způsoby používání konkrétních výrazových konstrukcí je proto nutné pečlivě zvažovat.

Fungování reprezentací učiva při didaktické transformaci obsahu klade určité nároky na jejich „podobu“ a „provedení“. Vyvstává otázka, jak by měly být reprezentace učiva koncipovány, aby podporovaly utváření žákovských prekonceptů a napomáhaly jejich přibližování k odpovídajícím konceptům oborovým. Několikrát jsme uvedli, že reprezentace mají smysl pouze jako intencionální vztah; tj. jako relace vztahované k určitému fenoménu. Je proto podstatné, aby relace mezi reprezentujícím objektem a reprezentovaným fenoménem byla asymetrická a jedinečná. A to z toho důvodu, aby umožňovala identifikovat nesprávné reprezentace (misreprezentace) spojené se zdůvodňováním (ne)správnosti.

Podstatným atributem je i „vzdálenost výrazové konstrukce“. Vzdálenost výrazové konstrukce lze chápat jako délku poznávací cesty, kterou žák musí urazit, aby se přiblížil poznání určitého fenoménu. V souvislosti s tím Slavík a Janík (2007, s. 272) popisují schéma významového kanálu mezi žákovi blízkými a žákovi vzdálenými reprezentacemi. Autoři konstatují, že významový kanál je utvářen na základě didaktického propojování (společného významu) výrazových konstrukcí užívaných žákem a výrazových konstrukcí užívaných experty oboru, zde reprezentovanými učitelem.

Požadavky týkající se fungování výrazových konstrukcí při transformování obsahu vzdělávání je možné odvodit také z principu odborné korektnosti. Princip odborné korektnosti odkazuje k požadavku, aby jak učitelský, tak žákovský projev byl významově co nejbližší analogickému projevu experta $\mathrm{v}$ daném oboru. $\mathrm{V}$ návaznosti na to by reprezentace zařazované do výuky měly odpovídat analogickým výrazovým konstrukcím expertů, ale zároveň zohledňovat kognitivní možnosti žáků. Jinými slovy, reprezentace by měly zprostředkovávat obsah bez nepřípustného zkreslení, ale zároveň s ohledem na výrazové prostředky žákůa jejich dosavadní zkušenosti (srov. Janík, Maňák, \& Knecht, 2009, s. 111-112). Podstatným faktorem ovlivňujícím fungování reprezentací ve výuce se ukazuje být také učitel, respektive jeho didaktické znalosti. Didaktické znalosti obsahu se odrážejí ve schopnosti učitele vybírat 
pro zpř́ístupňování a přibližování obsahu „adekvátní“ reprezentace učiva a zohledňovat přitom specifické potřeby žáků. (srov. např. Janík, 2009).

\section{Shrnutí a závěry}

V příspěvku byly představeny základní poznatky týkající se problematiky reprezentace, k nimž dospěly obory zabývající se zákonitostmi lidského poznávání, myšlení a učení. Cílem př́íspěvku bylo předložit některé úvahy směřující k rozpracování konceptu reprezentace pro potřeby didaktiky. V souvislosti s tím jsme se zaměřili na naznačení souvislostí mezi psychologickou teorií reprezentace a odpovídajícími didaktickými konstrukty. Představena byla také kognitivně psychologická a sociálně psychologická východiska konceptu.

Rozpracovávání konceptu reprezentace pro potřeby didaktiky je však do určité míry komplikováno odlišnými pojetími a nejednotným přístupem k výkladu a terminologii. Zatímco v kognitivní psychologii je koncept reprezentace uchopován $\mathrm{v}$ souvislosti se snahami o popsání procesů a mechanismů podílejících se na utváření vnitřního subjektivního světa jedince, v sociální psychologii se reprezentace uplatňuje při vysvětlování toho, do jaké míry je individuální poznávání jedince determinováno socio-kulturními faktory. Společné je však teoretické východisko, které vysvětluje reprezentaci jako odkazovací relaci - referenci reprezentujícího a reprezentovaného. $\mathrm{Z}$ didaktického hlediska představuje reprezentace klíčový koncept, který se uplatňuje při objasňování didaktické transformace obsahu vzdělávání a také při vysvětlování konceptuálního učení a konceptuální změny.

Didaktika se opírá jak o kognitivní, tak o sociálně psychologický přístup, protože musí pracovat jak s vnitřními obsahovými reprezentacemi subjektu, tak $\mathrm{s}$ jejich utvářením a přetvářením $\mathrm{v}$ sociálním a kulturním kontextu. Tato skutečnost byla vystižena odlišením tříalternativ existence reprezentovaného obsahu: (P) - subjektivní představa nebo prekoncept, (Q) - vnější výraz, resp. výrazová konstrukce vytvořená subjektem, (R) - kulturně etablovaná výrazová konstrukce.

Obory zabývající se různými aspekty konceptu reprezentace se při vysvětlování problematiky reprezentace mohou vzájemně doplňovat. To může přispívat $\mathrm{k}$ hlubšímu porozumění tomuto složitému fenoménu, který má ale značný explanační potenciál. Klíčové pro mezioborovou spolupráci je 
zejména výše vzpomenuté pochopení reprezentace jako reprezentující relace (resp. reference). 0 reprezentaci tak lze hovořit, pouze pokud jsou splněny určité faktické a logické podmínky, jak jsme uvedli výše.

V celkovém pohledu se ukazuje, že k hlubšímu porozumění konceptu reprezentace bude zapotřebí dalších výzkumů a související teoretizace. Jako žádoucí budoucí krok se jeví další rozpracování teorie didaktických reprezentací. Taková teorie by mohla významně přispět $\mathrm{k}$ řešení otázek vyvstávajících v souvislosti s re-prezentováním a transformováním obsahu v procesech vyučování a učení.

\section{Literatura}

Dennet, D. C. (2004). Druhy myslí. Praha: Academia.

Doulík, P., \& Škoda, J. (2010). Prekoncepce a miskoncepce jako součást dětských pojetí a jejich psychogeneze. In J. Škoda \& P. Doulík, et al., Prekoncepce a miskoncepce v oborových didaktikách (s. 8-29). Ústí n. Labem: Univerzita J. E. Purkyně.

Engelkamp, J., \& Pechmann, T. (1988). Kritische Anmerkungen zum Begriff der mentalen Repräsentation. Sprache und Kognition, 7(1), 2-11.

Eysenck, M. W., \& Keane, M. T. (2008). Kognitivní psychologie. Praha: Academia.

Goodman, N. (2007). Jazyky umění: nástin teorie symbolů. Praha: Academia.

Janík, T. (2009). Didaktické znalosti obsahu a jejich význam pro oborové didaktiky, tvorbu kurikula a učitelské vzdělávání. Brno: Paido.

Janík, T., \& Slavík, J. (2009). Obsah, subjekt a intersubjektivita v oborových didaktikách. Pedagogika, 59(2), 116-135.

Janík, T., Maňák, J., \& Knecht, P. (2009). Cíle a obsahy školního vzdělávání a metodologie jejich utváření. Brno: Paido.

Jelemenská, P. (2009). Model didaktické rekonstrukce z metodologického pohledu. In M. Janíková \& K. Vlčková, et al., Výzkum výuky: tématické oblasti, výzkumné př́stupy a metody (s. 145-170). Brno: Paido.

Jelemenská, P., Sander, E., \& Kattmann, U. (2003). Model didaktickej rekonštrukcie. Impulz pre výskum v odborných didaktikách. Pedagogika, 53(2), 190-201.

Johnson-Laird, P. N. (1983). Mental models: Towards a cognitive science of language, inference, and consciousness. Cambridge: Cambridge University Press.

Jorna, R. J. (1990). Knowledge representation and the symbols in the mind. Tübingen: Stauffenburg Verlag.

Mareš, J. (2001). Strukturování učiva, vyučovací a učební strategie. In J. Čáp \& J. Mareš (Eds.), Psychologie pro učitele (s. 441-465). Praha: Portál.

Marková, I. (2007). Dialogičnost a sociální reprezentace. Dynamika mysli. Praha: Academia.

Moscovici, S. (1961). La Psychoanalyse: son image et son pubic. Paris: Preses Universitaires de France.

Moscovici, S. (1985). Comment on Potter \& Litton. British JournalofSocial Psychology, 24 (2), 91-92. 
Najder, K. (1989). Reprezentacje i ich reprezentacje. Wrocław: WPAN.

Norman, D. A. (1979). Znania i rol'pamjati. Vopr. psichol., 24, 155-161.

Petrová, Z. (2008). Vygotského škola v pedagogike. Trnava: Vydavatel'stvo Trnavské univerzity.

Perner, J. (1993). Understanding the representational mind. Massachusetts: MIT Press.

Plichtová, J. (2002). Metódy sociálné psychologie zblízka. Kvantitatívne a kvalitativně skúmanie sociálnych reprezantácií. Bratislava: Média.

Ruisel, I., \& Ruiselová, Z. (1990). Vybrané problémy psychológie poznávania. Bratislava: Veda.

Shulman, L. S. (1986). Those who understand: Knowledge growth in teaching. Educational Researcher, 15(2), 4-11.

Shulman, L. S. (1987). Knowledge and teaching. Foundations of the new reform. Harvard Educational Review, 57(1), 1-22.

Sedláková, M. (1992). Příspěvek k analýze pojmu mentální reprezentace v soudobé psychologické teorii. Československá psychologie, 36(4), 289-308.

Sedláková, M. (2004). Vybrané kapitoly z kognitivní psychologie. Mentální reprezentace a mentální modely. Praha: Grada.

Slavík, J. (2011). K předmětu didaktik v estetických oborech vzdělávání. Pedagogická orientace, 21(2), 207-225.

Slavík, J., \& Janík, T. (2007). Fakty a fenomény v průniku didaktické teorie, výzkumu a praxe vzdělávání. Pedagogika, 57(3), 263-274.

Staub, F. C., West, L., \& Bickel, D. D. (2003). What is Content-focused coaching? In L. West \& F. C. Staub (Eds.), Content-focused coaching. Transforming mathematics lessons (s. 1-17). Portsmouth, NH: Heinemann.

Střiženec, M. (1982). Mentálne zobrazenie. Československá psychologie, 26(6), 534-545.

Štech, S. (2009). Zřetel k učivu a problém dvou modelů kurikula. Pedagogika, 59(2), 105-115.

Vygotskij, L. S. (2004). Psychologie myšlení a řeči. Praha: Portál.

\section{Autor}

Mgr. Tomáš Janko, Masarykova univerzita, Pedagogická fakulta, Institut výzkumu školního vzdělávání, Poříčí 31, Brno 603 00, e-mail: tjanko83@gmail.com

\section{Representations of content: psychological foundations and didactical background}

Abstract: This theoretical study concerns the issue of representations. Representation is a concept used when analysing and explaining human perception, cognition, communication, and learning. Firstly, we introduce the psychological foundations of the concept. Secondly, we clarify the concept of representations and its division in cognitive psychology. We define two basic forms of external representations - verbal 
and visual. In social psychology, the concept is used for explaining of how much individual cognition is determined by socio-cultural factors. Further, we mention the concept of representations that draws on the Theory of social representations (Moscovici) and Vygotsky's ideas. The author seeks to develop a concept of representations usable in didactic discourse. The importance of representations for content-oriented didactics is clarified. We also define the levels on which a teacher reasons when using representations during instruction. Representations of curricular content, which are believed to play an important role when presenting the content to students, are also mentioned.

Keywords: learning from representations, didactic transformation, educational content

Journal of Pedagogy (Pedagogický časopis) 2/2011

$\mathrm{V}$ druhém loňském čísle Pedagogického časopisu jsou uveřejněny tyto studie: Governmentality - Neoliberalism - Education: the Risk Perspektive (Ondrej Kaščák, Branislav Pupala), Controlled Freedom - the Formation of the Control Society (Ludwig A. Pongratz), Education Policy as Proto - fascism: The Aesthetics of the Control Society (P. Taylor Webb, Kalerno N. Gulson), Lunch Time at the Child Care Centre: Neoliberal Assemblages in Early Childhood Education (Fikile Nxumalo, Veronica Pacini - Ketchabaw, Mary Caroline Rowan), State Education as High - Yield Investment: Human Capital Theory in European Policy Discourse (Donald Gillies), Foucault, Governmentality, Neoliberalism and Adult Education - Perspective on the Normalization of Social Risks (Martin Kopecký), The Bologna Process as a New Public Management Tool in Higher Education (Stanislav Štech), The Business School in the Corporation of Higher Learning in the USA (Robert Kemp).

http://pdfweb.truni.sk/jop/ 